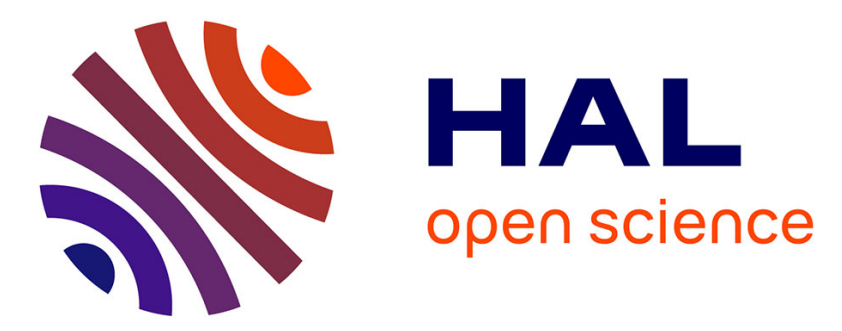

\title{
The influence of Bt-transgenic maize pollen on the bacterial diversity in the midgut of Apis mellifera ligustica
}

Li-Li Geng, Hong-Juan Cui, Ping-Li Dai, Zhi-Hong Lang, Chang-Long Shu, Ting Zhou, Fu-Ping Song, Jie Zhang

\section{To cite this version:}

Li-Li Geng, Hong-Juan Cui, Ping-Li Dai, Zhi-Hong Lang, Chang-Long Shu, et al.. The influence of Bt-transgenic maize pollen on the bacterial diversity in the midgut of Apis mellifera ligustica . Apidologie, 2013, 44 (2), pp.198-208. 10.1007/s13592-012-0171-8 . hal-01201287

\section{HAL Id: hal-01201287 \\ https://hal.science/hal-01201287}

Submitted on 17 Sep 2015

HAL is a multi-disciplinary open access archive for the deposit and dissemination of scientific research documents, whether they are published or not. The documents may come from teaching and research institutions in France or abroad, or from public or private research centers.
L'archive ouverte pluridisciplinaire HAL, est destinée au dépôt et à la diffusion de documents scientifiques de niveau recherche, publiés ou non, émanant des établissements d'enseignement et de recherche français ou étrangers, des laboratoires publics ou privés. 


\title{
The influence of Bt-transgenic maize pollen on the bacterial diversity in the midgut of Apis mellifera ligustica
}

\author{
Li-Li Geng ${ }^{1}$, Hong-Juan CuI ${ }^{1}$, Ping-Li DAI ${ }^{2}$, Zhi-Hong LAng ${ }^{3}$, Chang-Long Shu ${ }^{1}$, \\ Ting ZHou ${ }^{2}$, Fu-Ping Song ${ }^{1}$, Jie Zhang ${ }^{1}$

\begin{abstract}
${ }^{1}$ State Key Laboratory for Biology of Plant Diseases and Insect Pests, Institute of Plant Protection, Chinese Academy of Agricultural Sciences, Beijing 100193, People's Republic of China Academy of Agricultural Sciences, Beijing 100093, People's Republic of China
\end{abstract} \\ ${ }^{2}$ Key Laboratory of Pollinating Insect Biology, Ministry of Agriculture, Institute of Apicultural Research, Chinese \\ ${ }^{3}$ Biotechnology Research Institute, Chinese Academy of Agricultural Sciences, Beijing 100081, People's Republic of China
}

Received 8 June 2012 - Revised 5 September 2012 - Accepted 2 October 2012

\begin{abstract}
Honeybees are subjected to direct contact with transgenic maize pollen due to their feeding activities on pollen. The potential side effects of transgenic crylAh-maize pollen on the midgut bacteria of the larvae and worker bees of Apis mellifera ligustica were investigated through denaturing gradient gel electrophoresis under both laboratory and field conditions. Newly emerged bees were fed transgenic crylAhmaize pollen, normal maize pollen, linear crylAh gene DNA, supercoiled plasmid DNA, and sugar syrup under the laboratory conditions. The results showed that there were no significant differences in the midgut bacterial community composition among the five treatments. No significant effects were observed in the midgut communities between larvae and adult honeybees fed transgenic crylAh-maize pollen and non-transgenic maize pollen in the field trials.
\end{abstract}

transgenic maize / Apis mellifera / intestinal community / denaturing gradient gel electrophoresis

\section{INTRODUCTION}

Accumulated hectarage of genetically modified crops planted globally from 1996 to 2011 exceeds 1.6 billion ha (Clive 2012). Planting Bacillus thuringiensis $(\mathrm{Bt})$ crops effectively reduces the pesticide use by 443 million $\mathrm{kg}$ of active ingredient and has brought $\$ 34.2$ billion in economic benefits to date. In 2011, biotech maize covered 51 million ha and $32 \%$ of the global biotech area, and it was the second largest

Li-Li Geng and Hong-Juan Cui contributed equally to this work.

Corresponding author: J. Zhang, jzhang@ippcaas.cn

Manuscript editor: Monique Gauthier planted crop after cotton. However, the worldwide planting of $\mathrm{Bt}$ maize has triggered concerns about their potential impacts on the environment and human health. The main concern is the harmful effects that these crops may exert on nontarget organisms. Many studies demonstrate that transgenic maize with $c r y 1 A b, c r y 1 F$, or $c r y 3 B b$ gene do not exert harmful effects on nontarget arthropod (Gathmann et al. 2006; Higgins et al. 2009; Al-Deeb et al. 2003) and rhizosphere soil bacterial communities (Baumgarte and Tebbe 2005; Blackwood and Buyer 2004). The endophytic bacterial communities of maize were not significantly affected by transforming with cry $3 B b 1$, crylA105, or crylAb2 gene (Prischl et al. 2012). Meanwhile, no obvious changes have been observed in the decomposition of $c r y 1 \mathrm{Ab}$ - or 
cry $1 F$-maize residue (Daudu et al. 2009; Zwahlen et al. 2007; Gruber et al. 2012; Shan et al. 2008). Risk assessments and ecological effects of these commercialized Bt crops have been thoroughly investigated. But relatively few investigations focus on newly developed Bt crops which have the potential to be commercialized in the future.

Honeybees are economically valuable pollinators that are required for the seed production of many crops and wild plants. Because of their ecological and economic importance, they were widely considered as an important insect in the biosafety assessment of transgenic crops (Duan et al. 2008; Romeis et al. 2008). Gut bacteria coevolves with honeybees and plays an important role in honeybee health and growth. The effects of $\mathrm{Bt}$ maize on honeybees and gut bacterial structures of honeybees have been investigated. It was reported that syrups containing $\mathrm{Cry} 1 \mathrm{Ab}$ protoxin $(1,000 \mu \mathrm{g} / \mathrm{kg})$ did not affect syrup consumption and learning abilities of honeybees (RamirezRomero et al. 2005), whereas, pure CrylAc protein are unlikely to influence the development of honeybee larvae (Lima et al. 2011). Maize transformed with stacked Bt genes (crylA.105, cry $2 A b 2$, and $c r y 3 B b 1)$ or single gene (crylAb) showed no effects on the weight and survival of honeybee (Hendriksma et al. 2011; Rose et al. 2007). Exposure and feeding on crylAb-maize pollen did not harm the hypopharyngeal gland development of honeybees (Malone et al. 2004), and no significant effects on bacterial communities were observed (Babendreier et al. 2007).

Toxicity of Bt-toxin CrylAh to Ostrinia furnacalis is higher than that of the Cry1Ac, CrylAb, and Crylle proteins in our previous studies (Xue et al. 2008). CrylAh shared amino acid residue identity of $82 \%$ with $c r y l A b$ and $67 \%$ with $c r y l F$ which were widely used in commercialized $\mathrm{Bt}$ crops. Meanwhile, domain II of Cry1Ah was very similar to that of Cry1Ab and CrylAc, and domain III was similar to that of Cry1Ac. Transgenic maize harboring the crylAh gene performs well in controlling $O$. furnacalis larvae under both laboratory and field conditions (Wang et al. 2008) and has the potential to be commercialized. Their effects on honeybee development have been analyzed (Dai et al. 2012a, b). But there are no reports focused on the midgut bacterial structure fed with Bt-crylAh maize. In this study, the effects of transgenic Bt-crylAh maize pollen and high-dose foreign DNA (linear and superhelical plasmids) on the midgut bacterial community of worker bees (Apis mellifera ligustica) were first investigated under laboratory conditions; then, the influences of transgenic maize pollen on the midgut bacterial community of larvae and worker bees were studied in the field trials.

\section{MATERIALS AND METHODS}

\subsection{Insect, plant material, and DNA preparation}

A. mellifera ligustica was kindly provided by the Institute of Apicultural Research, Academy of Agricultural Sciences, Beijing, China. The transgenic maize (expressing the Bt-crylAh gene) and non-transgenic maize (X090) were provided by Biotechnology Research Institute, Chinese Academy of Agriculture Sciences (Beijing, China). The quantity of Cry1 Ah protein was $65.21 \mathrm{ng} / \mathrm{g}$ of maize pollen (Wang 2010).

Plasmid DNA (HF366) containing the crylAh gene was extracted using the AxyPre Plasmid Miniprep Kit (Axygen, USA) according to the manufacturer's protocol. The linear crylAh gene was extracted from the plasmid by digestion with BamHI.

\subsection{Laboratory feeding of honeybees}

Newly emerged bees (less than $12 \mathrm{~h}$ old) were assigned randomly to wooden cages $(22 \times 16 \times 6 \mathrm{~cm})$ with mesh on two sides. For each treatment, a total of 70 bees were used. All the cages were kept in a dark incubator at $29 \pm 1{ }^{\circ} \mathrm{C}$ and $65 \pm 5 \%$ relative humidity. Bees were fed sugar syrup $(60 \%(w / v)$ sucrose solution) from a gravity feeder fitted on each cage (Dai et al. 2012a). Five treatments were designed to examine the effects of Bt-transgenic maize pollen on the intestinal bacterial community of the honeybees. Pure sugar syrup $(60 \%(w / v)$ sucrose solution) served as a negative control. The other four treatments were $160 \mathrm{mg} / \mathrm{mL}$ of transgenic pollen, $160 \mathrm{mg} / \mathrm{mL}$ of non-transgenic pollen, $900 \mathrm{ng} / \mathrm{mL}$ of plasmid DNA, and $900 \mathrm{ng} / \mathrm{mL}$ of linear crylAh which 
were all mixed thoroughly in to sugar syrup (60\% $(w / v)$ sucrose solution). For each cage, $4 \mathrm{~mL}$ of the mixture was supplied every day. Bees were collected for further analysis after 15 days.

\subsection{Field feeding of honeybees}

Transgenic and non-transgenic maize were planted in two separated fields $(8 \times 50 \mathrm{~m}, 50 \mathrm{~m}$ apart) at the Langfang Experimental Station, Ministry of Agriculture China (Hebei Province, China) in July and August of 2010. Approximately 1,200 plantlets were planted per field plot in 12 rows with $0.5 \mathrm{~m}$ spacing between the rows. At the beginning of flowering, each plot was divided into three mesh cages $(8 \times 16 \mathrm{~m}$; height in the center, $3.5 \mathrm{~m}$ and mesh size, $1 \mathrm{~mm}$ ). Bee hives were set up in the center of mesh cages as described by Dai et al. (2012b). Three colonies of A. mellifera ligustica (10,000 honeybees per colony) were introduced per field plot. So the hives contained predominantly open and capped brood and eggs less than $48 \mathrm{~h}$ old that had been laid by the queen from the experimental hive. Larvae hatched shortly from these combs, and they were fed by worker bees which collected maize pollen in the field cages. The larvae were sampled after $0,3,6$, and 9 days, respectively. Adult bees were marked with enamel paint after emergence and collected 0,15 , and 30 days later, respectively.

\subsection{Honeybee dissection and DNA extraction}

The bees were placed at $-20{ }^{\circ} \mathrm{C}$ for an hour before dissection. The midguts of the honeybees were isolated in sterile conditions, and ten samples were collected for each treatment, kept in 2.0-mL eppendorf tubes, and stored at $-70{ }^{\circ} \mathrm{C}$. DNA extraction was performed according to the QIAamp DNA Stool Mini Kit protocol (QIAGEN, Germany).

\subsection{Amplification of the $16 \mathrm{~S}$ rDNA gene $\mathrm{V} 3$ region and DGGE analysis}

The V3 region of the 16S rDNA gene was amplified using primers 343f (5'-ACTCCTA
CGGGAGGCAGCAG-3') and 534r (5' ATTACCGCGGCTGCTGG-3') (Nakatsu et al. 2000). A "GC-clamp" (5'-CGCCCGCCG CGCGCGGCGGGCGGGG CGGGGGCCC GGGGG-3') was added to the $5^{\prime}$ end of the forward primer. PCR reactions were performed in a volume of $50 \mu \mathrm{L}$ containing $1.0 \mu \mathrm{L}$ DNA template, $1.0 \mu \mathrm{L}$ of each primer, and $25 \mu \mathrm{L} 2 \times$ Prime STAR Mix (TaKaRa). To reduce spurious PCR products, the touchdown procedure was used. We started with an annealing temperature of $65{ }^{\circ} \mathrm{C}$ for 1 cycle. The temperature was subsequently decreased by $1{ }^{\circ} \mathrm{C}$ every cycle until we reached a touchdown at $55{ }^{\circ} \mathrm{C}$, where a further 20 cycles was carried out in an Eppendorf Mastercycler Gradient thermocycler (Brinkman Instruments, Westbury, NY). The PCR products (about $230 \mathrm{bp}$ ) were separated by electrophoresis in agarose gels $(1 \%, w / v)$ and recovered with a DNA Gel Extraction Kit (AxyGEN, USA).

Denaturing gradient gel electrophoresis (DGGE) was performed using the D-code system (Bio Rad) with $8 \%(\mathrm{~m} / \mathrm{v})$ acrylamide (acrylamide/ bis-acrylamide, $37.5: 1 \mathrm{~m} / \mathrm{m})$. The gel contained a gradient of denaturant ranging from 35 to $50 \%$ (100\% denaturant is $7 \mathrm{~mol} / \mathrm{L}$ urea and $40 \%$ deionized formamide). Approximately $500 \mathrm{ng}$ of PCR products were mixed with $2 \times$ DGGE loading buffer, and DGGE was run at $200 \mathrm{~V}$ for $4 \mathrm{~h}$ at $60{ }^{\circ} \mathrm{C}$. After electrophoresis, the gel was stained with SYBR Green I (AMRESCO, USA) and visualized with UV illumination (Bio-Rad, USA). DGGE profiles were analyzed using Quantity One version software (BioRad). The phylogenetic clustering tree was constructed using the complete linkage method.

All the bands marked on the figure were collected, mashed, and then dipped in $100 \mu \mathrm{L}$ dd $\mathrm{H}_{2} \mathrm{O}$ overnight at $4{ }^{\circ} \mathrm{C}$. The solution $(5 \mu \mathrm{L})$ was taken as template and amplified with primers $343 \mathrm{f}$ and $534 \mathrm{r}$ using the above protocol. The PCR products (about $230 \mathrm{bp}$ ) were recovered, ligated into a pMDT-19 vector, and sequenced by Shanghai Sangon Biotechnology Co. (Shanghai, China). The tree shown was calculated by the Unweighted Pair Group Method with Arithmetic Mean (UPGMA) method implemented in the MEGA package. 


\subsection{Detection of horizontal gene transfer of full-length cry1Ah gene}

PCR was used to determine whether the fulllength crylAh gene $(2,040 \mathrm{bp})$ was transferred to the gut bacteria with the transgene-specific primers c r y 1 A h - F ( $5^{\prime}$ - G G G G A T C C A T C C T ATTTTAC- $\left.3^{\prime}\right)$ and cry 1 Ah-R (5'-GGTACC TTATCAAAGCT CGTC-3'). PCR conditions included an initial denaturing step for 4 min at $94{ }^{\circ} \mathrm{C}$ followed by 30 cycles of denaturing at $94{ }^{\circ} \mathrm{C}$ for $0.5 \mathrm{~min}$, annealing at $54{ }^{\circ} \mathrm{C}$ for $0.5 \mathrm{~min}$, and extension at $72{ }^{\circ} \mathrm{C}$ for $1.5 \mathrm{~min}$. The final elongation time was $10 \mathrm{~min}$ at $72{ }^{\circ} \mathrm{C}$.

\section{RESULTS}

\subsection{DGGE patterns of intestinal bacterial communities of adult honeybees under laboratory conditions}

The DGGE profiles of the bacterial 16S rDNA V3 region was generated from the midgut microbial community of honeybees fed on transgenic and non-transgenic maize pollen (Figure 1). The five feeding treatments were crylAh-maize pollen, non-transgenic maize pollen, pure sugar syrup, and sugar syrup with a crylAh plasmid or the linear
crylAh gene. The DGGE profiles of midgut microbial communities showed high diversity with large numbers of bands, and consistent bands specific to the five treatments were not observed. The dendrogram generated by this analysis contained three major clusters, separated at a minimum similarity level of approximately $56 \%$ (Figure 1). The transgenic treatment group II and non-transgenic treatment group II formed one separate cluster with approximately $71 \%$ of internal similarity (Figure 1). Almost all similarity coefficients between replicates were higher than that between treatments (Table I), except for the similarity between plasmid and linear DNA treatments $(\mathrm{Cs}=59.4)$, and the similarity between non-transgenic pollen and pure sugar syrup treatments $(\mathrm{Cs}=54.1)$. The likeness coefficient revealed that there were no significant differences between the midgut bacterial community structures of $A$. mellifera ligustica fed on transgenic pollen, non-transgenic pollen, pure sugar syrup, or a high concentration of foreign DNA.

For phylogenetic affiliation, the important clone sequences were aligned with closely related reference sequences (Martinson et al. 2011; Cox-Foster et al. 2007). Three clusters were identified, namely Betaproteobacteria,

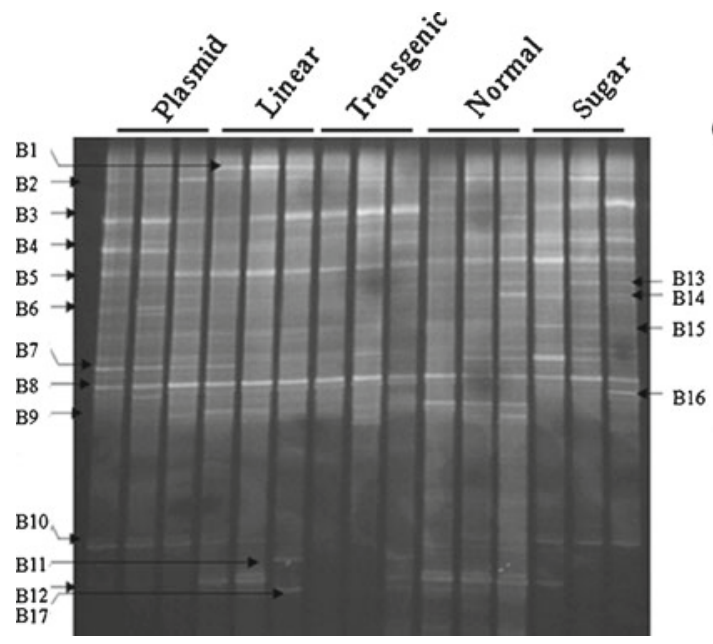

$\begin{array}{lllllllllllllllll}0.32 & 0.43 & 0.50 & 0.57 & 0.64 & 0.71 & 0.78 & 0.85 & 0.92 & 1.00\end{array}$

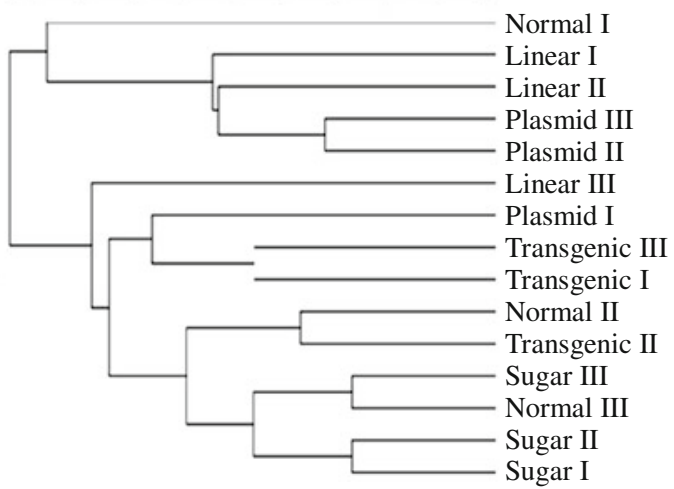

Figure 1. DGGE image and cluster analysis of gut bacterial community structure from honeybees feeding on laboratory conditions. 
Table I. Similarity coefficient (Cs) calculated from the DGGE banding patterns of bacterial communities from honeybees feeding on laboratory conditions.

\begin{tabular}{lccccc}
\hline & Plasmid & Linear & Transgenic & Normal & Sugar \\
\hline Plasmid & 59.4 & & & & \\
Linear & 59.4 & 66.8 & & & \\
Transgenic & 48.4 & 51.6 & 55.1 & 54.0 & \\
Normal & 51.1 & 53.1 & 51.0 & 54.1 & 58.3 \\
Sugar & 49.8 & 55.9 & 48.6 & \\
\hline
\end{tabular}

Gammaproteobacteria, and Firmicutes (Figure 2), which consistently occurred in bacterial community of honeybees (Martinson et al. 2011; Cox-Foster et al. 2007).

\subsection{DGGE patterns of intestinal bacterial communities of larvae fed under field conditions}

The DGGE patterns were generated from larvae samples collected $0,3,6$, or 9 days after fed on Bt-maize and non-transgenic maize pollen in field trials (Figure 3). Consistent bands specific to either Bt-maize pollen or non-transgenic pollen treatments were not observed. The dendrogram generated here indicated that samples collected from the same time tended to cluster, no matter what kind of diet they had. Moreover, the Bt-maize and nontransgenic pollen of 3 days' treatment formed two separate clusters with 78 and $74 \%$ similarity, respectively (Figure 3). Almost all the similarity coefficients between replicates were higher than that between treatments (Table II). The result indicated that crylAh-maize pollen did not clearly affect the midgut bacterial community structures of $A$. mellifera ligustica. For phylogenetic affiliation, the 11 clone sequences were aligned with closely related reference sequences. Three clusters were identified, namely Alphaproteobacteria, Gammaproteobacteria, and Firmicutes (Figure 4), which consistently occurred in bacterial community of honeybees. Most DGGE bands (Figure 3, B2, B3, B4, B6, B7, B9, and B11) showed the highest similarity to Gammaproteobacteria.

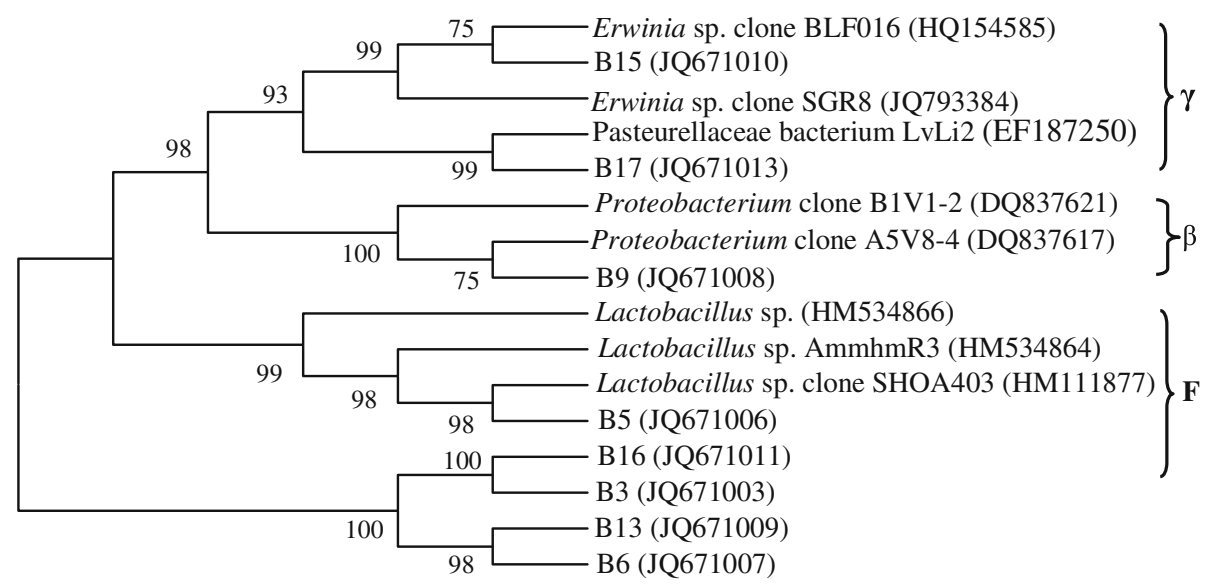

Figure 2. UPGMA dendrogram based on $16 \mathrm{~S}$ rRNA gene sequences from midgut bacteria of honeybees feeding on laboratory conditions and closely related reference sequences. 


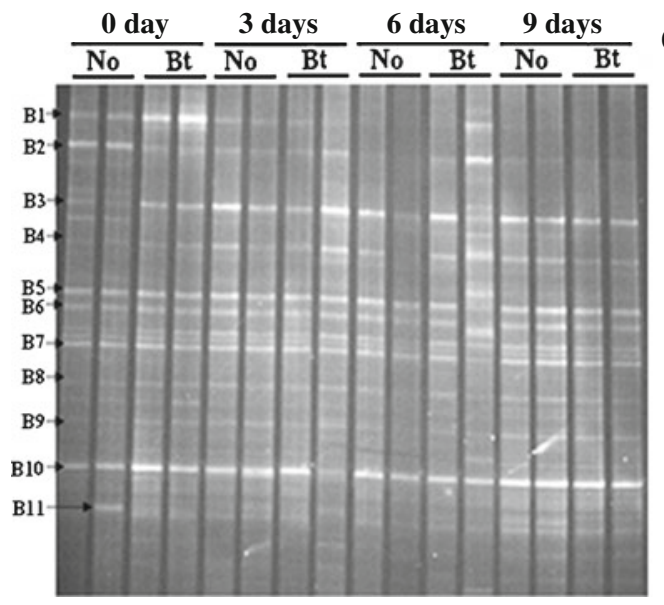

$\begin{array}{llllllllll}0.35 & 0.40 & 0.47 & 0.54 & 0.61 & 0.68 & 0.75 & 0.82 & 0.90 & 1.00\end{array}$

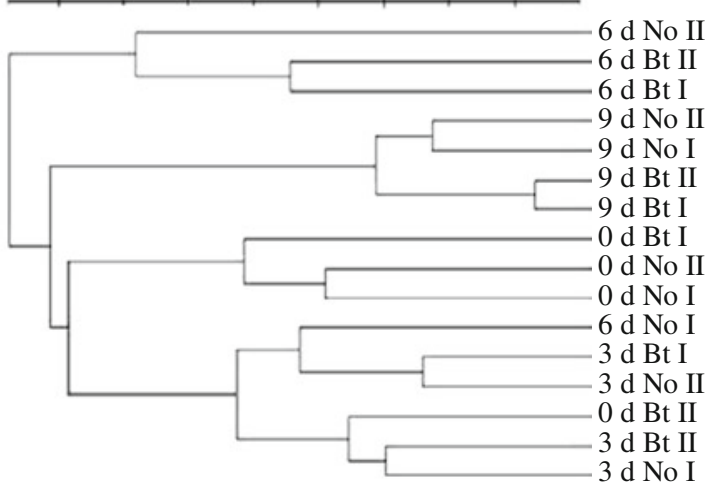

Figure 3. DGGE image and cluster analysis of gut bacterial community structure from larvae feeding under field conditions.

\subsection{DGGE patterns of intestinal bacterial communities of adult honeybees fed under field conditions}

The DGGE profiles were generated from adult samples collected 0,15 , or 30 days after fed on Btmaize and non-transgenic maize pollen in field trials (Figure 5). The dendrogram generated by this treatment contained three major clusters, and samples collected from the same time tended to cluster. Similar to the result of larva treatment, sampling time had a much more clear effect than Bt-maize pollen. The samples collected after 30 days' treatment on Bt-maize and nontransgenic pollen formed one separate cluster with
$70 \%$ similarity (Figure 5). All similarity coefficients between replicates were higher than that between treatments (Table III). Furthermore, similarity between the same time treatments was higher than that between different time points. The result indicated that no obvious effect was observed in the midgut bacterial community structures of adult honeybees fed on transgenic pollen and non-transgenic pollen in field trials. For phylogenetic affiliation, the 15 clone sequences formed three clusters, namely Betaproteobacteria, Gammaproteobacteria, and Firmicutes (Figure 6). The main cluster was Gammaproteobacteria which was the same as results in larva groups, whereas Alphaproteobacteria phylotype did not appear.

Table II. Similarity coefficient (Cs) calculated from the DGGE banding patterns of bacterial communities from larvae feeding on field conditions.

\begin{tabular}{|c|c|c|c|c|c|c|c|c|}
\hline & Od No & $0 \mathrm{~d} \mathrm{Bt}$ & $3 \mathrm{~d}$ No & $3 \mathrm{~d} \mathrm{Bt}$ & 6d No & $6 \mathrm{~d} \mathrm{Bt}$ & 9d No & $9 \mathrm{~d} \mathrm{Bt}$ \\
\hline Od No & 68.8 & & & & & & & \\
\hline $0 \mathrm{~d} B t$ & 47.8 & 69.1 & & & & & & \\
\hline $3 \mathrm{~d}$ No & 68.7 & 68.7 & 72 & & & & & \\
\hline $3 \mathrm{~d} \mathrm{Bt}$ & 63.9 & 73.8 & 73.8 & 71.5 & & & & \\
\hline 6d No & 51.8 & 59.9 & 57.4 & 57.4 & 41.7 & & & \\
\hline $6 \mathrm{~d} \mathrm{Bt}$ & 41.1 & 47.6 & 48.9 & 46.8 & 46.8 & 64.7 & & \\
\hline $9 \mathrm{~d}$ No & 37.8 & 48.4 & 48.0 & 44.6 & 50.9 & 50.9 & 79.5 & \\
\hline $9 \mathrm{~d} \mathrm{Bt}$ & 36.9 & 42.2 & 40.1 & 40.9 & 38.9 & 65.2 & 65.2 & 91.2 \\
\hline
\end{tabular}




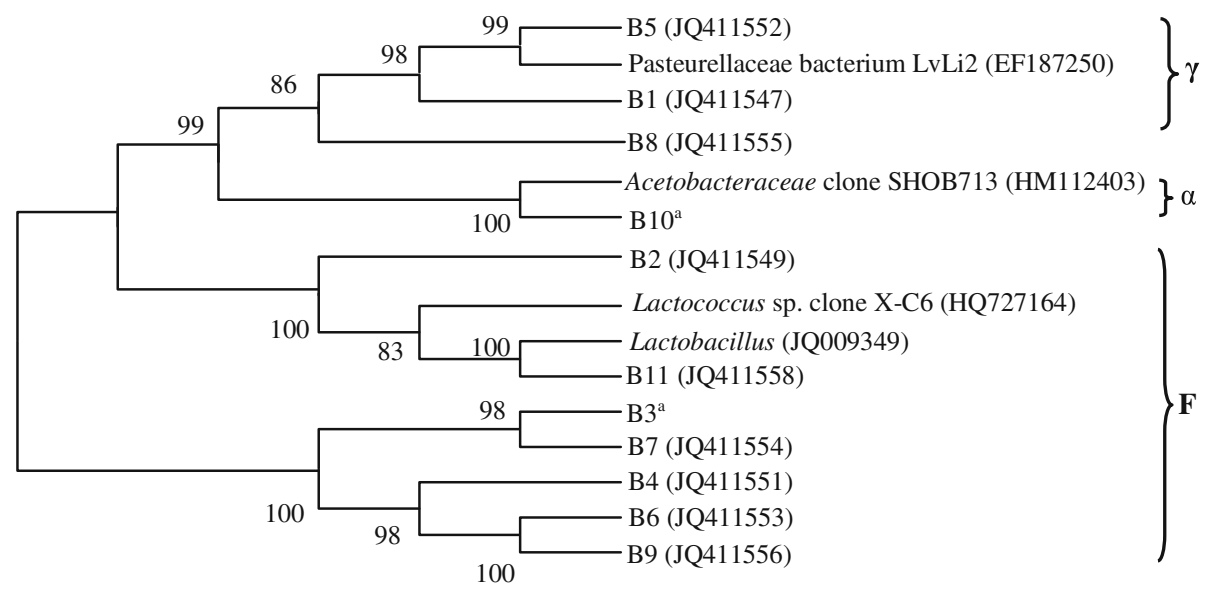

Figure 4. UPGMA dendrogram based on 16S rRNA gene sequences from midgut bacteria of larvae feeding under field conditions and closely related reference sequences.

\subsection{PCR detection of the full-length $c r y 1 A h$ gene in bacteria of the honeybee midgut}

Using crylAh-specific primers, horizontal transfer of the full-length crylAh gene to indigenous bacteria of $A$. mellifera ligustica was investigated. When genomic DNA from the gut bacteria was used as template, the whole crylAh gene $(\sim 2.0 \mathrm{~kb})$ was detected from the samples in the high-dose exogenous DNA (plasmid or linear DNA) treatment groups (Figure 7, lanes 5 and 7). Meanwhile, the crylAh band did not appear when samples digested with DNase I (TaKaRa) before bacterial genomic DNA extraction (Figure 7, lanes 6 and 8 ). No positive results were observed in the treatments of sugar syrup, non-transgenic pollen, and transgenic pollen under laboratory conditions (Figure 7, lanes 2 to 4). No bands

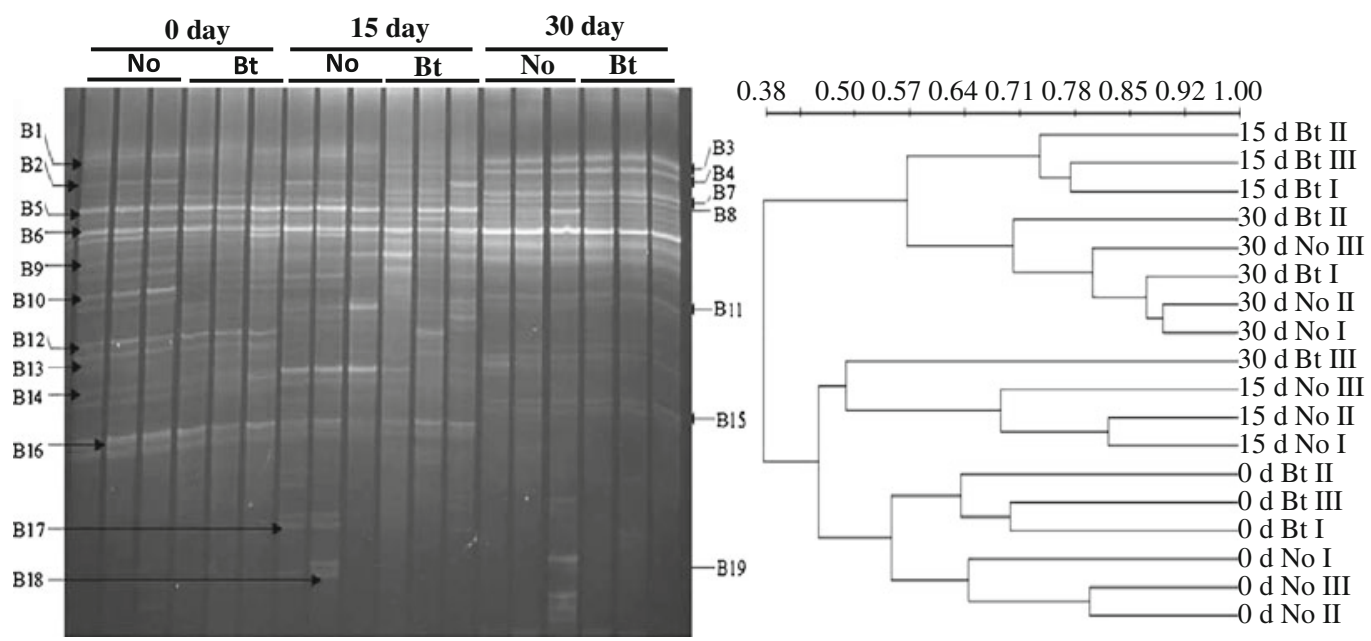

Figure 5. DGGE image and cluster analysis of gut bacterial community structure from adult honeybees feeding under field conditions. 
Table III. Similarity coefficient (Cs) calculated from the DGGE banding patterns of bacterial communities from adult feeding on field conditions.

\begin{tabular}{lcccccc}
\hline & $0 \mathrm{~d}$ No & 0d Bt & $15 \mathrm{~d}$ No & $15 \mathrm{~d} \mathrm{Bt}$ & $30 \mathrm{~d}$ No & $30 \mathrm{~d} \mathrm{Bt}$ \\
\hline $0 \mathrm{~d} \mathrm{No}$ & 69.4 & & & & & \\
$0 \mathrm{~d} \mathrm{Bt}$ & 53.2 & 56.0 & & & & \\
$15 \mathrm{~d} \mathrm{No}$ & 38.3 & 43.8 & 55.4 & & & \\
$15 \mathrm{~d} \mathrm{Bt}$ & 45.2 & 47.7 & 49.5 & 60.5 & & \\
$30 \mathrm{~d} \mathrm{No}$ & 38.2 & 43.1 & 41.0 & 58.8 & 82.5 & 74.3 \\
$30 \mathrm{~d} \mathrm{Bt}$ & 36.3 & 46.2 & 36.6 & 50.6 & 73.1 & \\
\hline
\end{tabular}

appeared both in non-transgenic pollen and transgenic pollen treatment of larvae and adult honeybees in field trials (Figure 7, lanes 9 to 12). Thus, we concluded that the full-length crylAh gene from transgenic pollen or highdose treatments did not transfer to indigenous bacteria in the midgut of $A$. mellifera ligustica.

\section{DISCUSSION}

Only one study evaluated the potential risk of purified Bt-protein and Bt-maize pollen on gut bacterial communities of honeybees, and no significant effects were observed (Babendreier et al. 2007). However, the effects of Bt- expressing maize on midgut bacterial communities of $A$. mellifera ligustica under field conditions have not been investigated yet. In this study, the effects of transgenic maize pollen containing Bt-Cry1Ah toxin on midgut bacterial communities of both larvae and adult of honeybees (A. mellifera ligustica) were investigated in the field trails, and no obvious differences were observed. Furthermore, no significant differences were found in midgut bacterial structures among newly emerged honeybees fed on transgenic crylAhmaize pollen, normal maize pollen, linear crylAh gene DNA, supercoiled plasmid DNA,

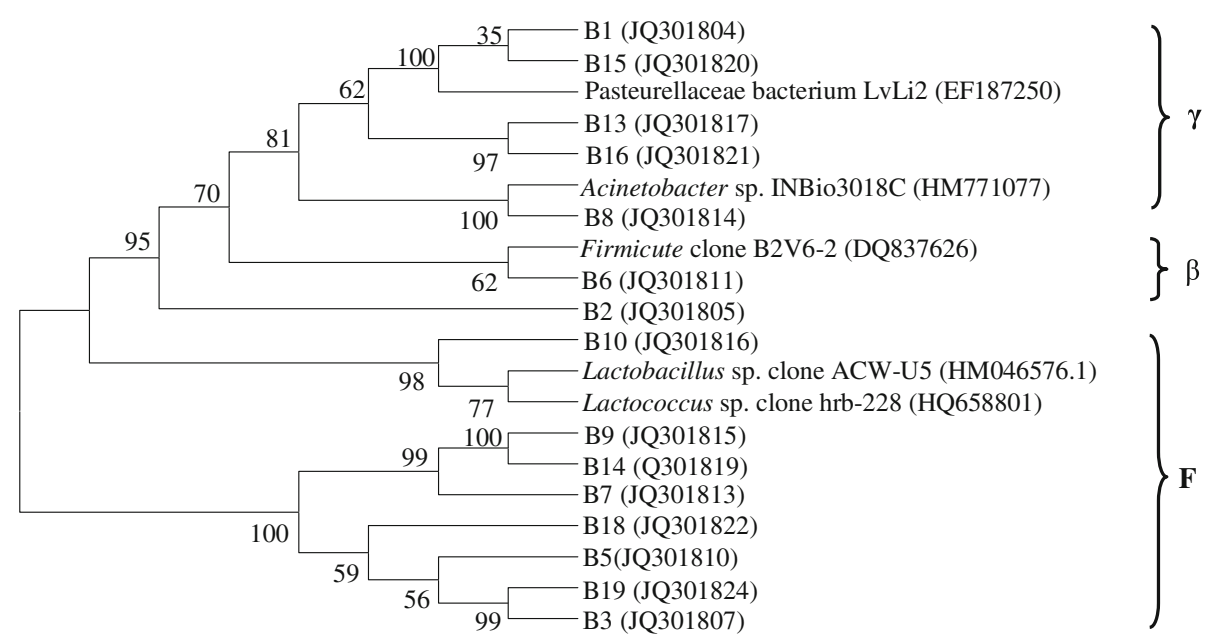

Figure 6. UPGMA dendrogram based on $16 \mathrm{~S}$ rRNA gene sequences from midgut bacteria of adult bees feeding under field conditions and closely related reference sequences. 


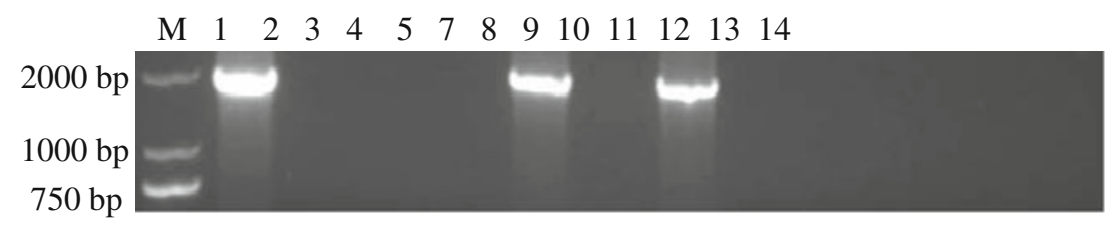

Figure 7. Detection of horizontal transfer of full-length crylAh gene by PCR.

and sugar syrup under the laboratory conditions. These results were consistent with previous explorations (Babendreier et al. 2007). Moreover, larva and adult honeybee samples collected at the same time, whether fed with transgenic maize pollen or normal pollen, tended to cluster in the field trails according to DGGE profiles. The effect of different sampling time periods was greater than that of diet treatments. Additionally, the number of midgut bacteria of adult honeybees was higher than that of larvae, which might be influenced by different gut structure.

The dominant midgut bacterial population of A. mellifera ligustica, which were $\alpha-, \beta-, \gamma-$ Proteobacteria and Firmicutes, were the same as previously reported for Apis cerana (Yoshiyama and Kimura 2009) and A. mellifera (Mohr and Tebbe 2006; Martinson et al. 2011; Cox-Foster et al. 2007). Furthermore, in this study, members of the Gammaproteobacteria were found to be the most common group of bacteria in honeybee midguts as in intestines (Babendreier et al. 2007). But the diversity found was relatively low as compared with these studies.

The full-length $c r y l A h$ gene from transgenic pollen or high-dose DNA treatments were not transferred to indigenous bacteria in the midgut of $A$. mellifera ligustica, which was consistent with the results of bees fed with herbicideresistant (transformed with pat gene) oilseed rape pollen (Mohr and Tebbe 2007). This demonstrated that neither a full-length crylAh gene nor a partial pat gene (386 of $800 \mathrm{bp}$ ) integrated into the genome of gut bacteria. Thus, it cannot be excluded that horizontal gene transfer took place at a very low rates. If more pairs of primer were used, the results should be more convincing.
In the environmental risk assessment of biotech crops, honeybee is a key species. The results here indicated that there were no significant direct adverse effects of transgenic crylAh maize pollen on the midgut bacterial community composition of $A$. mellifera ligustica in both laboratory and field conditions.

\section{ACKNOWLEDGMENTS}

This work was supported by grants from the Major State Basic Research Development Program of China (973 Program; No. 2009CB118902) and the National Transgenic Major Program of China (No. 2009ZX08011-016B).

L'influence du pollen de maïs-Bt transgénique sur la diversité bactérienne de l'intestin moyen d'Apis mellifera ligustica

Maïs transgénique / Apis mellifera / flore intestinale / électrophorèse sur gel à gradient dénaturant

Der Einfluss von Bt-transgenem Maispollen auf die bakterielle Diversität im Mitteldarm von Apis mellifera ligustica

transgener Mais / Apis mellifera / Darmflora / denaturierende Gradientengelelektrophorese

\section{REFERENCES}

Al-Deeb, M.A., Wilde, G.E., Blair, J.M., Todd, T.C. (2003) Effect of Bt corn for corn rootworm control on nontarget soil microarthropods and nematodes. Environ. Entomol. 32, 859-865

Babendreier, D., Joller, D., Romeis, J., Bigler, F., Widmer, F. (2007) Bacterial community structures in honeybee intestines and their response to two insecticidal proteins. FEMS Microbiol. Ecol. 59, $600-610$ 
Baumgarte, S., Tebbe, C.C. (2005) Field studies on the environmental fate of the CrylAb Bt-toxin produced by transgenic maize (MON810) and its effect on bacterial communities in the maize rhizosphere. Mol. Ecol. 14, 2539-2551

Blackwood, C.B., Buyer, J.S. (2004) Soil microbial communities associated with $\mathrm{Bt}$ and non-Bt corn in three soils. J. Environ. Qual. 33, 832-836

Clive J. (2012) Global Status of Commercialized Biotech/GM Crops: 2011. ISAAA Brief No. 432011

Cox-Foster, D.L., Conlan, S., Holmes, E.C., Palacios, G., Evans, J.D., Moran, N.A., Quan, P.L., Briese, T., Hornig, M., Geiser, D.M. (2007) A metagenomic survey of microbes in honey bee colony collapse disorder. Science 318, 283-287

Dai, P.L., Zhou, W., Zhang, J., Jiang, W.Y., Wang, Q., Cui, H.J., Sun, J.H., Wu, Y.Y., Zhou, T. (2012a) The effects of Bt Cry1Ah toxin on worker honeybees (Apis mellifera ligustica and Apis cerana cerana). Apidologie 43, 384-391

Dai, P.L., Zhou, W., Zhang, J., Cui, H.J., Wang, Q., Jiang, W.Y., Sun, J.H., Wu, Y.Y., Zhou, T. (2012b) Field assessment of Bt crylAh corn pollen on the survival, development and behavior of Apis mellifera ligustica. Ecotoxicol. Environ. Saf. 79, 232237

Daudu, C.K., Muchaonyerwa, P., Mnkeni, P.N.S. (2009) Litterbag decomposition of genetically modified maize residues and their constituent Bacillus thuringiensis protein $(\mathrm{Cry} 1 \mathrm{Ab})$ under field conditions in the central region of the Eastern Cape, South Africa. Agric. Ecosyst. Environ. 134, 153-158

Duan, J.J., Marvier, M., Huesing, J., Dively, G., Huang, Z.Y. (2008) A meta-analysis of effects of Bt crops on honey bees (Hymenoptera: Apidae). PLoS One 3, e1415

Gathmann, A., Wirooks, L., Hothorn, L.A., Bartsch, D., Schuphan, I. (2006) Impact of $\mathrm{Bt}$ maize pollen (MON810) on lepidopteran larvae living on accompanying weeds. Mol. Ecol. 15, 2677-2685

Gruber, H., Paul, V., Meyer, H.H.D., Müller, M.M. (2012) Determination of insecticidal CrylAb protein in soil collected in the final growing seasons of a nine-year field trial of Bt-maize MON810. Transgenic Res. 21, 77-78

Hendriksma, H.P., Härtel, S., Steffan-Dewenter, I. (2011) Testing pollen of single and stacked insect-resistant Bt-maize on in vitro reared honey bee larvae. PLoS One 6, e28174

Higgins, L.S., Babcock, J., Neese, P., Layton, R.J., Moellenbeck, D.J., Storer, N. (2009) Three-year field monitoring of Cry1F, event DAS-Ø15Ø7-1, maize hybrids for nontarget arthropod effects. Environ. Entomol. 38, 281-292

Lima, M.A.P., Pires, C.S.S., Guedes, R.N.C., Nakasu, E.Y.T., Lara, M.S., Fontes, E.M.G., Sujii, E.R., Dias, S.C., Campos, L.A.O. (2011) Does Cry1Ac Bt-toxin impair development of worker larvae of
Africanized honey bee? J. Appl. Entomol. 135, 415422

Malone, L.A., Todd, J.H., Burgess, E.P.J., Christeller, J.T. (2004) Development of hypopharyngeal glands in adult honey bees fed with a Bt toxin, a biotinbinding protein and a protease inhibitor. Apidologie 35, 655-664

Martinson, V.G., Danforth, B.N., Minckley, R.L., Rueppell, O., Tingek, S., Moran, N.A. (2011) A simple and distinctive microbiota associated with honey bees and bumble bees. Mol. Ecol. 20, 619-628

Mohr, K.I., Tebbe, C.C. (2006) Diversity and phylotype consistency of bacteria in the guts of three bee species (Apoidea) at an oilseed rape field. Environ. Microbiol. 8, 258-272

Mohr, K., Tebbe, C. (2007) Field study results on the probability and risk of a horizontal gene transfer from transgenic herbicide-resistant oilseed rape pollen to gut bacteria of bees. Appl. Microbiol. Biot. 75, 573-582

Nakatsu, C.H., Torsvik, V., Ovreas, L. (2000) Soil community analysis using DGGE of $16 \mathrm{~s}$ rDNA polymerase chain reaction products. Soil Sci. Soc. Am. J. 64, 1382-1388

Prischl, M., Hackl, E., Pastar, M., Pfeiffer, S., Sessitsch, A. (2012) Genetically modified Bt maize lines containing $c r y 3 B b 1$, cry $1 A 105$ or $c r y 1 A b 2$ do not affect the structure and functioning of rootassociated endophyte communities. Appl. Soil Ecol. 54, 39-48

Ramirez-Romero, R., Chaufaux, J., Pham-Delegue, M. (2005) Effects of CrylAb protoxin, deltamethrin and imidacloprid on the foraging activity and the learning performances of the honeybee Apis mellifera, a comparative approach. Apidologie 36, 601-611

Romeis, J., Bartsch, D., Bigler, F., Candolfi, M.P., Gielkens, M.M.C., et al. (2008) Assessment of risk of insect-resistant transgenic crops to nontarget arthropods. Nat. Biotechnol. 26, 203-208

Rose, R., Dively, G.P., Pettis, J. (2007) Effects of Bt corn pollen on honey bees: emphasis on protocol development. Apidologie 38, 368-377

Shan, G., Embrey, S.K., Herman, R.A., McCormick, R. (2008) Cry1F protein not detected in soil after three years of transgenic Bt corn (1507 corn) use. Environ. Entomol. 37, 255-262

Wang Y.F. (2010) Field trails and genetic stability analysis of insect resistant transgenic $\mathrm{Bt}$ maize. Ph.D. dissertation, Northeast Agricultural University, Heilongjiang

Wang, Y.B., Lang, Z., Zhang, J., He, K.L., Song, F.P., Huang, D.F. (2008) Ubil intron-mediated enhancement of the expression of $\mathrm{Bt} c r y 1 A h$ gene in transgenic maize (Zea mays L.). Chin. Sci. Bull. 53, 3185-3190

Xue, J., Liang, G., Crickmore, N., Li, H., He, K., Song, F., Feng, X., Huang, D., Zhang, J. (2008) Cloning and characterization of a novel Cry1A toxin from 
Bacillus thuringiensis with high toxicity to the Asian corn borer and other lepidopteran insects. FEMS Microbiol. Lett. 280, 95-101

Yoshiyama, M., Kimura, K. (2009) Bacteria in the gut of Japanese honeybee, Apis cerana japonica, and their antagonistic effect against Paenibacillus larvae, the causal agent of American foulbrood. J. Invertebr. Pathol. 102, 91-96

Zwahlen, C., Hilbeck, A., Nentwig, W. (2007) Field decomposition of transgenic $\mathrm{Bt}$ maize residue and the impact on non-target soil invertebrates. Plant Soil 300, 245-257 